TITLE:

\title{
RECORD OF FAVORINUS \\ TSURUGANUS N. SP., FROM \\ TSURUGA BAY, JAPAN \\ (NUDIBRANCHIA-EOLIDOIDEA)
}

\section{$\operatorname{AUTHOR}(\mathrm{S}):$}

Baba, Kikutaro; Abe, Takeo

\section{CITATION:}

Baba, Kikutaro ...[et al]. RECORD OF FAVORINUS TSURUGANUS N. SP., FROM TSURUGA BAY, JAPAN (NUDIBRANCHIA-EOLIDOIDEA). PUBLICATIONS OF THE SETO MARINE BIOLOGICAL LABORATORY 1964, 12(2): 163-164

ISSUE DATE:

1964-10-15

URL:

http://hdl.handle.net/2433/175358

RIGHT: 


\title{
RECORD OF FAVORINUS TSURUGANUS N. SP., FROM TSURUGA BAY, JAPAN (NUDIBRANCHIA-EOLIDOIDEA)
}

\author{
KIKUTARÔ BABA \\ Biological Laboratory, Osaka Gakugei University, Osaka \\ and \\ TAKEO ABE \\ Takaoka High School, Takaoka, Toyama Pref.
}

With 1 Text-figure

During the surveying work of ours on the Opisthobranch fauna of the Japan Sea side of Japan, we have been fortunate to obtain a graceful specimen of Favorinus which will be recorded here as representing a new form.

Favorinus tsuruganus BABA \& ABE, n. sp.

Tsuruga-chigo-minoumiushi (n. n.)

Length of body (Code Ac) $15 \mathrm{~mm}$. General body-form in the living state as usual in the genus (after preservation the animal was too greatly damaged to allow of the precise description of the external features in relation to the liver system). Cephalic tentacles exceedingly long and fine, the rhinophores shorter and provided each with 2 bulbs at about the mid-length, the footcorners tentaculiform, the tail tapering, and the smooth branchial papillae elongated fusiform. Main part of body colourless and translucent, but there is a faint tinge of yellow covering the head-region. The whole length of the rhinophores deep black. Each of the branchial papillae marked with black near the end on the outside; the vein (= liver diverticulum) of these structures orange-yellow. Entire length of the jaw-edge armed with a row of spiny denticles followed by 3-4 rows of much smaller ones. Radula formula $16 \times 0.1 .0$. Central tooth typically $\mathrm{V}$-shaped, and without lateral denticles.

Type locality: Mizushima, Tsuruga Bay, Japan Sea side of Japan, shore. Date of collection: July 30, 1956 ( 1 sp., coll. by us).

Publ. Seto Mar. Biol. Lab., XII (2), 1964. (Article 12) 


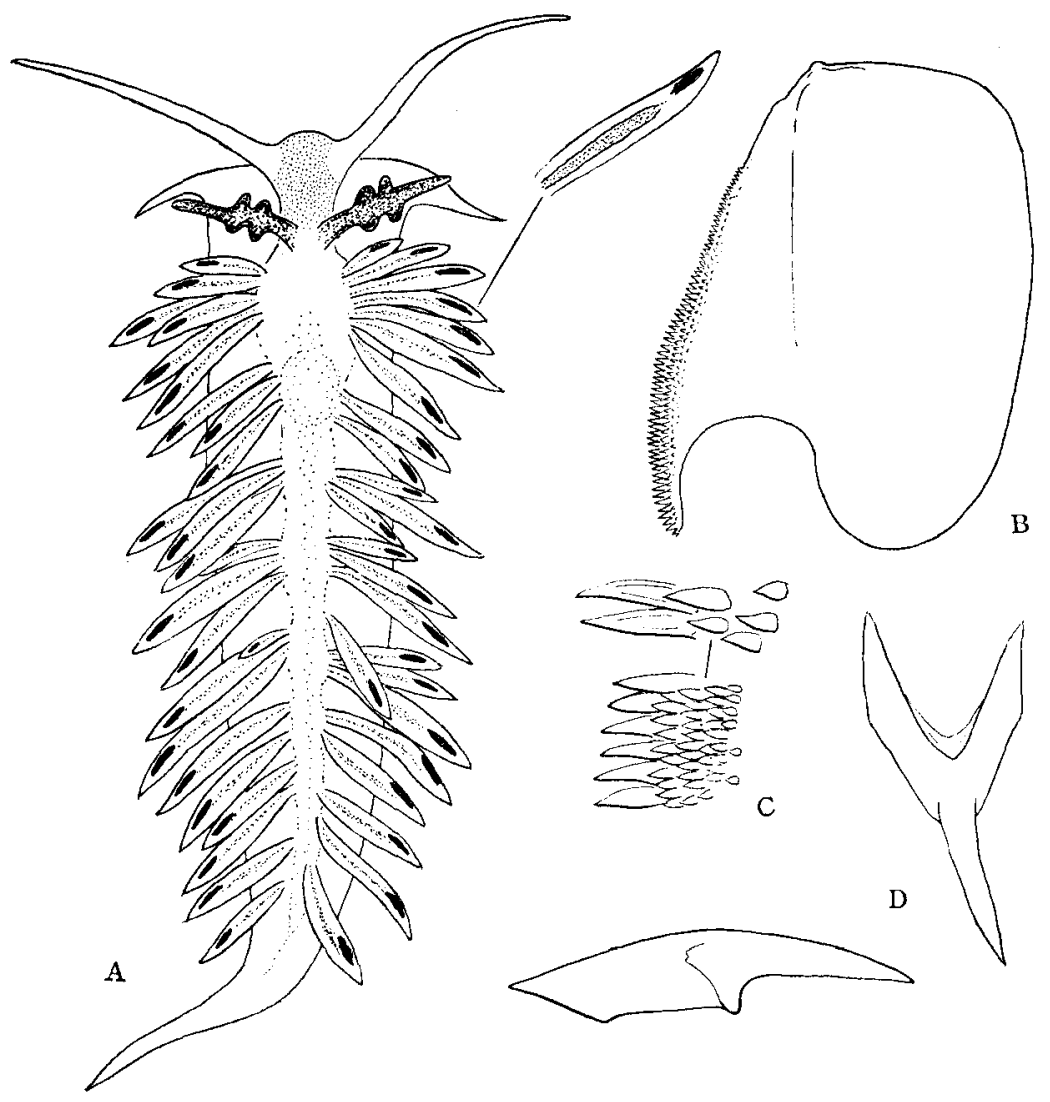

Fig. 1. Favorinus tsuruganus from Tsuruga Bay, Japan Sea side of Japan. A. Entire animal in life, dorsal view, length (Code Ac) $15 \mathrm{~mm}$. B. Left jaw-plate $(\times 60)$, C. Rows of spiny denticles on the jawedge $(\times 330)$. D. Central teeth from above and from side $(\times 200)$. 